Provided for non-commercial research and education use. Not for reproduction, distribution or commercial use.

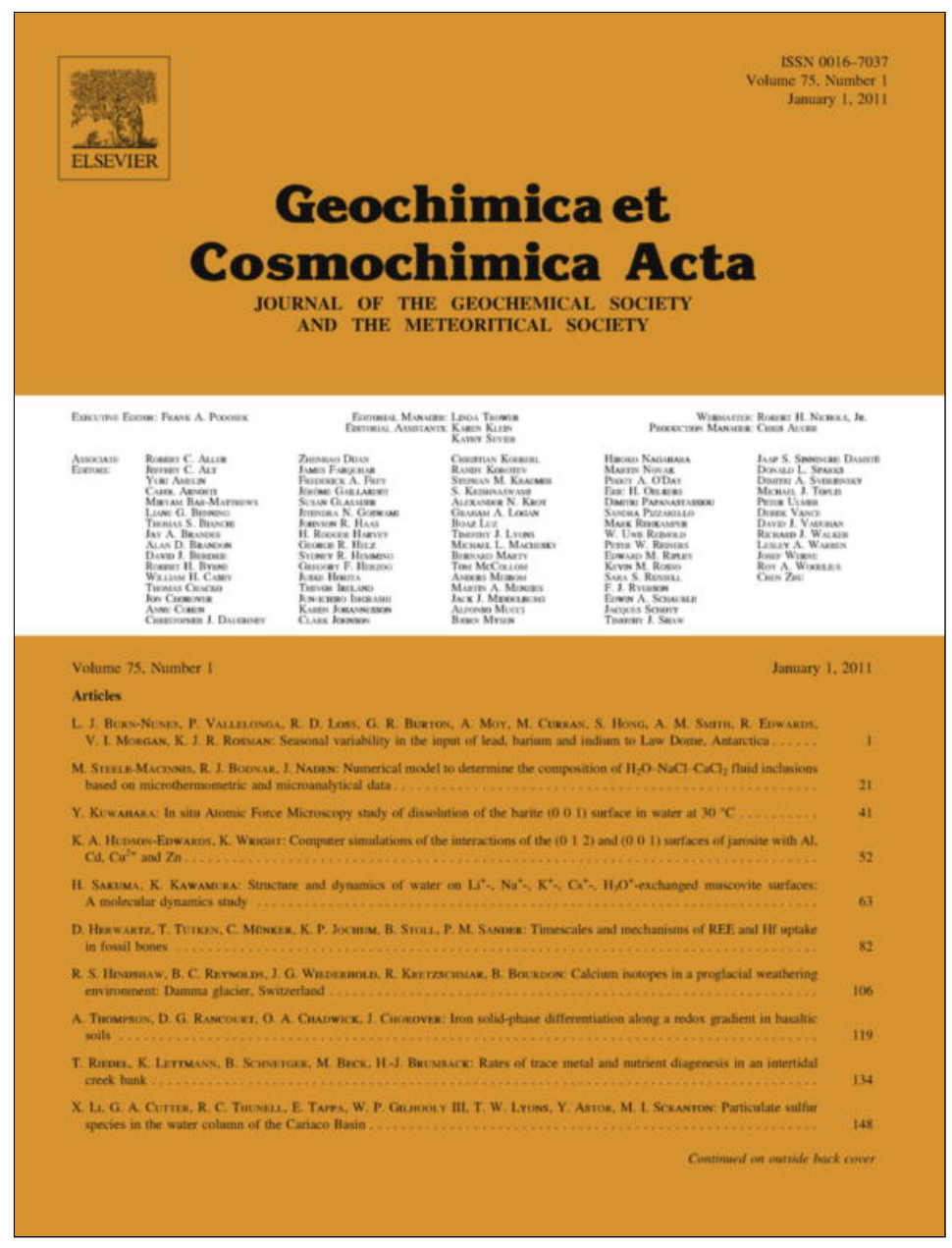

(This is a sample cover image for this issue. The actual cover is not yet available at this time.)

This article appeared in a journal published by Elsevier. The attached copy is furnished to the author for internal non-commercial research and education use, including for instruction at the authors institution and sharing with colleagues.

Other uses, including reproduction and distribution, or selling or licensing copies, or posting to personal, institutional or third party websites are prohibited.

In most cases authors are permitted to post their version of the article (e.g. in Word or Tex form) to their personal website or institutional repository. Authors requiring further information regarding Elsevier's archiving and manuscript policies are encouraged to visit:

http://www.elsevier.com/copyright 


\title{
Uranium speciation and stability after reductive immobilization in aquifer sediments
}

\author{
Jonathan O. Sharp ${ }^{\mathrm{a}, *}$, Juan S. Lezama-Pacheco ${ }^{\mathrm{b}}$, Eleanor J. Schofield ${ }^{\mathrm{b}}$, \\ Pilar Junier $^{\mathrm{a}, 1}$, Kai-Uwe Ulrich ${ }^{\mathrm{c}, 2}$, Satya Chinni ${ }^{\mathrm{d}}$, Harish Veeramani ${ }^{\mathrm{a}}$, \\ Camille Margot-Roquier ${ }^{\mathrm{a}}$, Samuel M. Webb ${ }^{\mathrm{b}}$, Bradley M. Tebo ${ }^{\mathrm{d}}$, \\ Daniel E. Giammar ${ }^{\mathrm{c}}$, John R. Bargar ${ }^{\mathrm{b}}$, Rizlan Bernier-Latmani ${ }^{\mathrm{a}}$ \\ ${ }^{a}$ Environmental Microbiology Laboratory, École Polytechnique Fédérale de Lausanne, CH-1015 Lausanne, Switzerland \\ ${ }^{\mathrm{b}}$ Stanford Synchrotron Radiation Lightsource, 2575 Sand Hill Rd, Menlo Park, CA 94025, United States \\ ${ }^{\mathrm{c}}$ Department of Energy, Environmental and Chemical Engineering, Washington University, One Brookings Drive, \\ St. Louis, MO 63130, United States \\ ${ }^{\mathrm{d}}$ Department of Environmental and Biomolecular Systems, Oregon Health \& Science University, $20000 \mathrm{NW}$ Walker Rd, Beaverton, OR \\ 97006, United States
}

Received 29 December 2010; accepted in revised form 11 August 2011

\begin{abstract}
It has generally been assumed that the bioreduction of hexavalent uranium in groundwater systems will result in the precipitation of immobile uraninite $\left(\mathrm{UO}_{2}\right)$. In order to explore the form and stability of uranium immobilized under these conditions, we introduced lactate ( $15 \mathrm{mM}$ for 3 months) into flow-through columns containing sediments derived from a former uranium-processing site at Old Rifle, CO. This resulted in metal-reducing conditions as evidenced by concurrent uranium uptake and iron release. Despite initial augmentation with Shewanella oneidensis, bacteria belonging to the phylum Firmicutes dominated the biostimulated columns. The immobilization of uranium ( $\sim 1 \mathrm{mmol} \mathrm{U}$ per $\mathrm{kg}$ sediment $)$ enabled analysis by Xray absorption spectroscopy (XAS). Tetravalent uranium associated with these sediments did not have spectroscopic signatures representative of $\mathrm{U}-\mathrm{U}$ shells or crystalline $\mathrm{UO}_{2}$. Analysis by microfocused XAS revealed concentrated micrometer regions of solid U(IV) that had spectroscopic signatures consistent with bulk analyses and a poor proximal correlation ( $\mu \mathrm{m}$ scale resolution) between $\mathrm{U}$ and $\mathrm{Fe}$. A plausible explanation, supported by biogeochemical conditions and spectral interpretations, is uranium association with phosphoryl moieties found in biomass; hence implicating direct enzymatic uranium reduction. After the immobilization phase, two months of in situ exposure to oxic influent did not result in substantial uranium remobilization. Ex situ flow-through experiments demonstrated more rapid uranium mobilization than observed in column oxidation studies and indicated that sediment-associated U(IV) is more mobile than biogenic $\mathrm{UO}_{2}$. This work suggests that in situ uranium bioimmobilization studies and subsurface modeling parameters should be expanded to account for nonuraninite U(IV) species associated with biomass.
\end{abstract}

(C) 2011 Elsevier Ltd. All rights reserved.

\footnotetext{
* Corresponding author. Present address: Civil and Environmental Engineering, Colorado School of Mines, Golden, CO 80401, United States. Tel.: +1 303273 3473; fax: +1 3032733413. E-mail address: jsharp@mines.edu (J.O. Sharp).

${ }^{1}$ Present address: Laboratory of Microbiology, University of Neuchatel, Neuchatel 2000, Switzerland.

${ }^{2}$ Present address: BGD Soil and Groundwater Laboratory, Tiergartenstrasse 48, D-01219 Dresden, Germany.
}

\section{INTRODUCTION}

The aqueous mobility of uranium is strongly influenced by its redox state with the oxidized form prevailing as a mobile, soluble species under many environmental settings. For this reason, microbial reduction has been proposed as an in situ strategy for immobilizing uranium in groundwater (Lovley et al., 1991). Laboratory studies have focused on 
understanding uranium precipitation when it is mediated by dissimilatory metal- or sulfate-reducing bacteria (DMRB and DSRB) (Lovley and Phillips, 1992). Structural analyses have revealed that uranium precipitates produced by phylogenetically and metabolically diverse bacteria are conserved as clusters of nano-uraninite $\left(\mathrm{UO}_{2}\right)$ (Burgos et al., 2008; Schofield et al., 2008; Sharp et al., 2009). Despite this apparent independence from biological variability, extrapolation to a more biogeochemically complex subsurface is not well understood.

Flow-through sediment columns amended with DMRB (Moon et al., 2007) and a mixed culture containing DSRB (Gu et al., 2005) have confirmed that uranium can be immobilized in these environmentally relevant systems, and real-time X-ray absorption spectroscopy has shown in situ evidence for reduced uranium associated with column sediments (Komlos et al., 2008a). Month-long batch incubations of sediments in the presence of uranium show reduction and precipitation of the radionuclide (Suzuki et al., 2002). Similarly, microbial activity has been shown to drive uranium immobilization in pilot field studies (Anderson et al., 2003; Wu et al., 2007) and has been integrated into subsurface fate and transport models (Yabusaki et al., 2007).

However, the intricacy of chemical and physical processes complicates mechanistic interpretations. Subsurface uranium immobilization can result from interplay between enzymatic reduction, sorption, and reactions with abiotic reductants. Reduction or sorption of uranyl by $\mathrm{Fe}(\mathrm{II})$-bearing minerals, which can be present or formed as a result of biological reductive processes, has been reported for ferrous sulfides (Wersin et al., 1994), green rust (O'Loughlin et al., 2003), and Fe(II) sorbed onto goethite (Fredrickson et al., 2000). Similarly, incorporation of oxidized uranium into phosphate minerals (Jerden and Sinha, 2003; Singh et al., 2010) and sorption of U(VI) onto biomass has also been demonstrated to play a role in uranium immobilization (N'Guessan et al., 2008). Analyses of uranium-contaminated sediments in Oak Ridge, TN support the notion of competing mechanisms and concurrent immobilization of both oxidized and reduced species of uranium (Zhou and $\mathrm{Gu}, 2005)$. This last study identified U(VI)-phosphates, $\mathrm{U}(\mathrm{VI})$-organic complexes, and U(VI) sorbed onto minerals, in addition to reduced U(IV), but did not resolve more detailed properties of the U(IV) phases. There is also increasing evidence that $\mathrm{U}(\mathrm{IV})$ species other than uraninite can form as a result of enzymatic (Bernier-Latmani et al., 2010; Ray et al., 2011; Sivaswamy et al., 2011) and abiotic $\mathrm{U}(\mathrm{VI})$ reduction (Veeramani et al., 2011), even in the absence of sediments.

Not surprisingly, the multiplicity of biogeochemical interactions complicate determinations of the structure and fine-scale distribution of uranium present in sediments as well as the corresponding stability of subsurface-immobilized uranium. The spectroscopic characterization of uranium in field samples is subject to interference by compounds such as rubidium and is precluded by the relatively high concentration required for reliable in situ U-EXAFS (Anderson et al., 2003; Kelly et al., 2008; Suzuki et al., 2002). Previous column studies, which represent a more controlled system for manipulating uranium concentrations in the presence of sediments, do not provide detailed EXAFS analysis of the immobilized uranium $(\mathrm{Gu}$ et al., 2005; Moon et al., 2007; Komlos et al., 2008a). In this study, we overcome uranium concentration limitations to evaluate sediment columns stimulated for concomitant iron and uranium reduction. After 71 days of in-column reduction, bulk and microprobe X-ray absorption spectroscopy analyses were coupled to reveal the distribution and speciation of uranium in these sediments. These analyses were complemented by investigations of dominant bacterial lineages as well as by chemical digestions to determine uranium distribution and speciation. The stability of the immobilized uranium was assessed in the columns as well as in flow-through reactors. The objective of this study is to better understand the structure and stability of uranium associated with sediments during dissimilatory metal reduction.

\section{MATERIALS AND METHODS}

\subsection{Sediment column design}

Column studies were adapted from published methods (Moon et al., 2007). Each of three $15 \mathrm{~cm}$ long by $4.8 \mathrm{~cm}$ diameter glass chromatography columns fitted with diffusive caps (Kimble-Kontes, Vineland, NJ) were completely filled with $<2 \mathrm{~mm}$ sieved sediments (Rifle Area Background Sediments (RABS) $\sim 40 \%$ porosity) derived from a former uranium processing site at Old Rifle, CO (Anderson et al., 2003). RABS was wet packed with harvested LuriaBertani (LB)-grown Shewanella oneidensis MR-1 (ca. $100 \mathrm{mg} \mathrm{L}^{-1}$ protein) suspended in $30 \mathrm{mM}$ bicarbonate solution. In parallel to the two active columns, a control column was amended with the same quantity of deactivated and washed biomass that had been incubated in formaldehyde.

Low-oxygen influent $(30 \mathrm{mM}$ bicarbonate, $2 \mathrm{mM}$ $\mathrm{NH}_{4} \mathrm{Cl}, 0.2 \mathrm{mM}$ trisodium trimetaphosphate, and $55 \mu \mathrm{M}$ uranyl acetate) was prepared by boiling Milli-Q water followed by the addition of salts and cooling under a $\mathrm{CO}_{2}: \mathrm{N}_{2}(15: 85)$ gas stream to reach an equilibrium $\mathrm{pH}$ of $7.5 \pm 0.2$. Rifle groundwater $\mathrm{pH}$ ranges from 7.2 to 7.4 and $\mathrm{U}_{(\mathrm{aq})}$ ranges from 0.4 to $1.8 \mu \mathrm{M}$ (Anderson et al., 2003); higher influent uranyl was introduced in our experiments to enable spectroscopic analyses. Trimetaphosphate (TMP) rather than orthophosphate was used to minimize the potential for U(VI)-phosphate precipitation (Abdelouas et al., 1998). Residence time and breakthrough characteristics were determined by measuring the effluent bromide concentration (introduction of $30 \mathrm{mg} \mathrm{L}^{-1} \mathrm{NaBr}$ ). The media was transferred to purged $3 \mathrm{~L}$ Nalgene Cantene ${ }^{\mathrm{TM}}$ flasks followed by the removal of all headspace to conserve dissolved inorganic carbon (DIC) and limit oxygen introduction. Viton and Masterflex tubing and polypropylene barbed connectors were used to connect the system. Influent was delivered up-flow through the column at a rate of $6.1 \pm 0.2 \mathrm{~mL} \mathrm{~h}^{-1}$ through the duration of the experiment (Ismatec IP, Glattbrugg, Switzerland) resulting in a calculated hydraulic residence time of $17.4 \pm 0.6 \mathrm{~h}$. A stock of 
$1 \mathrm{M}$ lactate (lactic acid adjusted to $\mathrm{pH}=7$ with $\mathrm{NaOH}$ ) was introduced by syringe pump (KD scientific, Holliston, MA) between the reservoir and column for an influent concentration of $15 \mathrm{mM}$. While in the same magnitude, this concentration is higher than related sediment flow-through bioreduction studies that used $3-10 \mathrm{mM}$ acetate for biostimulation (Komlos et al., 2008a; N'Guessan et al., 2008).

After 71 days of reductive immobilization, one of the active columns (AC-1) and the formaldehyde control (DC) were sacrificed for sediment analysis. The remaining active column (AC-2) was then exposed to oxic influent for an additional 64 days of flow. Column design and flow were similar to those described above with the omission of lactate and macronutrients and the addition of oxygen. The influent consisted of $30 \mathrm{mM}$ bicarbonate buffered under a $\mathrm{CO}_{2}: \mathrm{O}_{2}: \mathrm{N}_{2}(15: 20: 65)$ atmosphere to a $\mathrm{pH}$ of $7.4 \pm 0.2$ and $7.8 \pm 0.3 \mathrm{mg} \mathrm{O}_{2} \mathrm{~L}^{-1}$. As before, influent was transferred to purged collapsible flasks followed by the removal of all headspace to conserve DIC.

\subsection{Analysis of column influent and effluent}

Fractions of the effluent were collected in test tubes for future analysis using an IS-95 Interval Sampler (Spectrum Chromotography, Houston, TX). Acid extractable Fe(II) was stabilized in $0.1 \mathrm{M} \mathrm{HCl}$ and analyzed with ferrozine (Stookey, 1970). Samples analyzed for total uranium and organics were collected without acidification. Influent and effluent were analyzed for soluble U(VI) using a kinetic phosphorescence analyzer (KPA-11A; Chemchek Instruments, Richland, WA). Organic acids were measured using an ion chromatograph (DX-3000, Dionex, Sunnyvale, CA) with an IonPac AS11-HC column. Elution was carried out using a gradient of $0.5-40 \mathrm{mM} \mathrm{KOH}$. Bromide was quantified using a Dionex DX-500 with an AS12A column and isocratic gradient of $30 \mathrm{mM} \mathrm{KOH}$. Dissolved oxygen and $\mathrm{pH}$ were analyzed using $\mathrm{LDO}$ and $\mathrm{pH}$ probes attached to a Hach HQ4d meter (Loveland, CO). Analysis for total inorganic carbon (TIC) involved acidified samples measured in a Shimadzu TOC-VCSN.

\subsection{Column sediment analyses}

At the termination of the column experiment, sediments were separated vertically into three fractions (inflow, middle and outflow sections) in an anaerobic glove box (3:97 $\mathrm{H}_{2}: \mathrm{N}_{2}$ ). Each fraction was homogenized, sealed, and purged under high purity $\mathrm{N}_{2}$ flow followed by storage under dark, anaerobic conditions. Subsequent analyses were conducted from days up to two months after storage. While AC-1 and DC were sampled immediately after the uranium reduction phase, AC-2 was sampled after prolonged (64 days) in situ treatment with oxygenated influent.

Uranium in the column sediments was quantified using two different methods. In the first, known amounts of dry solid $(\sim 100 \mathrm{mg})$ were digested in Aqua Regia (3:1 mixture by volume of concentrated $\mathrm{HCl}$ and $\mathrm{HNO}_{3}$ ) at $150{ }^{\circ} \mathrm{C}$ using commercial digestion bombs and quantified for $\mathrm{U}_{\mathrm{T}}$ by ICPMS. The second method involved mass balance differentiation between $U_{T}$ and redox species (Phillips et al., 1995) that used triplicates of $\sim 0.1 \mathrm{~g}$ of sediments in $10 \mathrm{~mL}$ of degassed $0.5 \mathrm{M} \mathrm{NaHCO}_{3}$ solution ( $\mathrm{pH} 8.2 \pm 0.2$ ). Mobile $\mathrm{U}(\mathrm{VI})$ associated with the reduced sediments was quantified by KPA after anoxic extraction. To measure $\mathrm{U}_{\mathrm{T}}$, an aggressive oxidative extraction was employed that utilized $5 \mathrm{~mL}$ of $0.5 \mathrm{M}$ potassium persulfate and air to oxidize all $\mathrm{U}$ in the system followed by KPA analysis. After 10-12 h of mixing, each extracted suspension was filtered through a $0.02 \mu \mathrm{m}$ Anotop syringe filter (Whatman); $\mathrm{U}$ adsorbed to the filter was recovered and quantified by washing the filter with $0.5 \mathrm{M}$ bicarbonate. U(IV) was calculated as the difference between $\mathrm{U}_{\mathrm{T}}$ and extracted $\mathrm{U}(\mathrm{VI})$.

\subsection{Bacterial community analysis in column sediments}

A subsequent column immobilization study involving three active columns was conducted in order to identify key microorganisms inhabiting the columns. Columns were similar in all respects to those described previously. Approximately $1 \mathrm{~g}$ of sediments was collected from the middle part of each sacrificial column $(4.5-9 \mathrm{~cm})$ at 11 , 35 , and 75 days. Sediments were immediately frozen in sterile epitubes at $-20^{\circ} \mathrm{C}$; DNA was subsequently extracted from two fractions ( $500 \mathrm{mg}$ of sediment each) using the Power Soil DNA kit (MoBio) and pooled for analysis. The bacterial 16S rRNA gene was amplified by PCR in three separate reactions using universal bacterial primers 27F (5'-GAG TTT GAT CCT GGC TCA G-3') and 1542R (5'-AGA AAG GAG GTG ATC CAG CC-3') (Joulian et al., 1998; Lane, 1991). Individual PCR reactions were pooled, purified (Qiagen PCR Purification), cloned (Invitrogen TOPO TA) and sequenced (Fasteris SA, Geneva, Switzerland). The sequences were analyzed using BLASTN (http://blast.ncbi.nlm.nih.gov/Blast.cgi). Unique clones were deposited in GenBank under accession numbers HQ660783-HQ660807. Phylogenetic analyses were carried out using ARB software (http://www.arb-home.de) as described elsewhere (Purkhold et al., 2003). Briefly, 16S rRNA gene sequences and their closest matches in BLAST were integrated and aligned into the ARB database; alignments were corrected manually. A phylogenetic tree was constructed using the PHYLIP subroutine in ARB with the neighbor-joining algorithm using a Kimura-calculated distance matrix.

\subsection{Bulk XAS characterization of sediments}

Structural synchrotron and spectroscopic characterizations of sediment-associated uranium employed extended X-ray absorption fine structure (EXAFS). All sample manipulation at SSRL was carried out under an anaerobic atmosphere (5\% hydrogen, balance nitrogen) as described previously (Schofield et al., 2008; Sharp et al., 2009). Sediments derived from the inflow section of active columns were loaded in $\mathrm{Al}$ sample holders with Kapton windows. $\mathrm{U} \mathrm{L}_{\mathrm{II}}$-edge fluorescene spectra were selected for EXAFS to mitigate interference of the $\mathrm{U} \mathrm{L}_{\alpha}$ emission line from the rubidium $\mathrm{K}_{\alpha}$ line. Direct comparison of $\mathrm{L}_{\mathrm{II}^{-}}$and $\mathrm{L}_{\mathrm{III}^{-}}$ edge EXAFS for $\mathrm{UO}_{2}$ revealed subtle changes that do not affect qualitative assessments relating to the presence of 
the $\mathrm{U}-\mathrm{U}$ shell as shown in the electronic annex (Fig. EA-1); hence $\mathrm{L}_{\mathrm{II}}$ and $\mathrm{L}_{\mathrm{III}}$-edge EXAFS from the same coordination environment are assumed to be directly comparable. $\mathrm{U} \mathrm{L}_{\mathrm{III}}$-edge spectra were employed for XANES. Spectra were collected at SSRL beamlines 11-2 and 10-2 at $77 \mathrm{~K}$, using Si (220) double-crystal monochromators. EXAFS spectra were pre-processed with SIXPACK (Webb, 2005); they were then background subtracted, splined and analyzed using IFEFFIT coupled to ATHENA and ARTEMIS (Newville, 2001; Ravel and Newville, 2005). Backscattering phase and amplitude functions required for fitting of spectra were obtained from FEFF 8 (Rehr and Albers, 2000).

\subsection{X-ray microprobe imaging (micro-XAS) of sediment matrix}

Microprobe XAS analysis began by impregnating anaerobically dried column material (inflow fraction of AC-1 and AC-2) with Epotek 301 (Epoxy Technologies, Billerica, MA). A polished $2.5 \mathrm{~cm} \times 2.5 \mathrm{~cm} \times 30 \mu \mathrm{m}$ thin-section was prepared by Spectrum Petrographics (Vancouver, WA). Synchrotron micro-fluorescence maps of thin-sections were measured at SSRL beam line 2-3. Beam size on the sample was approximately $2 \mu \mathrm{m} \times 2 \mu \mathrm{m}$ at full width half-maximum using Pt-coated Kirkpatrick-Baez (K-B) focusing optics (X-Radia). X-ray fluorescence data were recorded using a single element Si Vortex detector (SSI). Monochromatic X-rays were selected using a water cooled $\mathrm{Si}(111) \mathrm{phi}=90$ double crystal monochromator. The Xray energy was calibrated to the first inflection point of the Y K-edge $(E=17,038 \mathrm{eV})$.

Maps were collected by continuous raster scanning at multiple incident energies $(17,100,17,170,17,175,17,178$ and $17,190 \mathrm{eV}$ ) to provide fluorescence intensities at several distinguishing points within the $\mathrm{U} \mathrm{L}_{\mathrm{III}}$-edge. Fluorescence counts were normalized to the measured intensity of the incident energy of the X-ray beam $\left(I_{0}\right)$. The background counts measured at $17,100 \mathrm{eV}$ below the $\mathrm{U} \mathrm{L}_{\mathrm{III}}$-edge (edge $=17,166 \mathrm{eV}$ ) were subtracted from the above the edge energies to correct for rubidium interference $(\mathrm{Rb}$ edge $=15,200 \mathrm{eV}, \quad \mathrm{Rb} \mathrm{K}_{\alpha}$ fluorescence $=13,396 \mathrm{eV}, \mathrm{U}$ $\mathrm{L}_{\alpha}=13,614 \mathrm{eV}$ ). To determine the $\mathrm{U}$ oxidation states in the sample, a linear least squares fitting was performed at each pixel in the map of each of the edge energies mapped to normalized intensities of standard U(IV) and U(VI) compounds (Pickering et al., 2000; Marcus, 2010). The following values of U(IV) and U(VI) intensities were used: 17,170: 1.04,0.61; 17,175: 1.72,1.28; 17,178: 1.61,1.46; 17,190: 0.98, 1.18. Fluorescence maps were analyzed using the Microanalysis Toolkit (http://smak.sams-xrays.com/) and SIXPACK (Webb, 2005).

\subsection{Uranium mobilization from sediments by continuous-flow experiments}

Rates of $\mathrm{U}$ release from bioreduced column sediments derived from the inflow section of column AC-1 were determined under oxidizing and reducing conditions using continuous-flow stirred tank reactors (CFRs). Details of design and operation are described elsewhere (Ulrich et al., 2008, 2009). The CFRs were loaded in the anaerobic chamber (5:95 $\left.\mathrm{H}_{2}: \mathrm{N}_{2}\right)$ with weighed sediment (8.1$\left.8.6 \mathrm{~g} \mathrm{~L}^{-1}\right)$ and sealed with $0.2 \mu \mathrm{m}$ pore-size polycarbonate filter membranes (Millipore GTTP, USA). The first continuous-flow experiment was run for about 60 residence times ( $\tau=19-22 \mathrm{~min}$ ), and was performed under oxidizing conditions by feeding air-equilibrated Milli-Q water spiked with a $30 \mathrm{mM} \mathrm{NaHCO} 3$ solution (pH 7.5). A flow-through oxygen miniprobe (Microelectrodes Inc., Bedford, NH) monitored the concentration of dissolved oxygen (DO) in the effluent tubing between the CFR and effluent sampler (fraction collector). After about $2 \tau$, the DO concentrations of the effluent matched the air-saturated DO concentration of the influent.

The second experiment applied a series of influent solutions in succession of increasing ability to mobilize uranium as a function of carbonate and oxygen concentration. The feeding sequence started with anoxic and carbonate-free, $5 \mathrm{mM}$ HEPES containing Milli-Q water buffered at $\mathrm{pH}$ 7.5. This was followed by the same solution spiked with $1 \mathrm{mM} \mathrm{NaHCO} 3(\mathrm{pH} 7.5)$ in the presence of a $1 \% \mathrm{vol} p \mathrm{O}_{2}$ headspace to simulate sub-oxic groundwater. The third condition maintained the same bicarbonate concentration but increased dissolved oxygen to air-saturated conditions $\left(\sim 21 \%\right.$ vol $\left.p \mathrm{O}_{2}\right)$. Each dissolution experiment was carried out in two replicate reactors at room temperature $\left(20 \pm 1^{\circ} \mathrm{C}\right)$ and in the dark. Reactors were operated at flow rates that achieved residence times of 7.5-15 $\mathrm{min}$; the residence time was stable over a given condition. Flow rates were selected to allow the determination of different pools of uranium based on their relative release rates and not in an effort to simulate aquifer conditions.

\section{RESULTS}

\subsection{Uranium immobilization in sediment columns}

\subsubsection{Evolution of soluble components in influent and effluent}

Columns loaded with sediment (RABS) were optimized for metal reduction to enable subsequent analyses (Fig. 1). Three parallel flow-through columns were bioaugmented with washed inoculations of either active (columns labeled AC-1 and AC-2) or deactivated (DC) suspensions of $S$. oneidensis MR-1. Lactate, a commonly employed electron donor for Shewanella spp. stimulation, was selected to provide optimal conditions for bioaugmentation with this facultative anaerobe. The addition of formaldehyde-exposed DC cells at this stage provided a similar quantity of metabolically inactive biomass while not otherwise altering sediment properties or indigenous microorganisms. The influent averaged $55 \pm 2 \mu \mathrm{M}$ uranyl with a theoretical residence of $18 \mathrm{~h}$ as confirmed by bromide tracer tests (Fig. 1, inset). Effluent recordings provided strong evidence for uranium bioreduction in all columns with an increase in rates of removal consistent with community adaptation (Fig. 1A). Despite differences in time points for the achievement of $98 \%$ removal of U(VI) from the dissolved phase $(\mathrm{AC}-1=37$ days, $\mathrm{AC}-2=24$ days, $\mathrm{DC}=58$ days $)$, removal curves were characterized by similar maximum slopes of $2.5 \pm 0.2 \mu \mathrm{M} \mathrm{U} \mathrm{d}^{-1}$. 

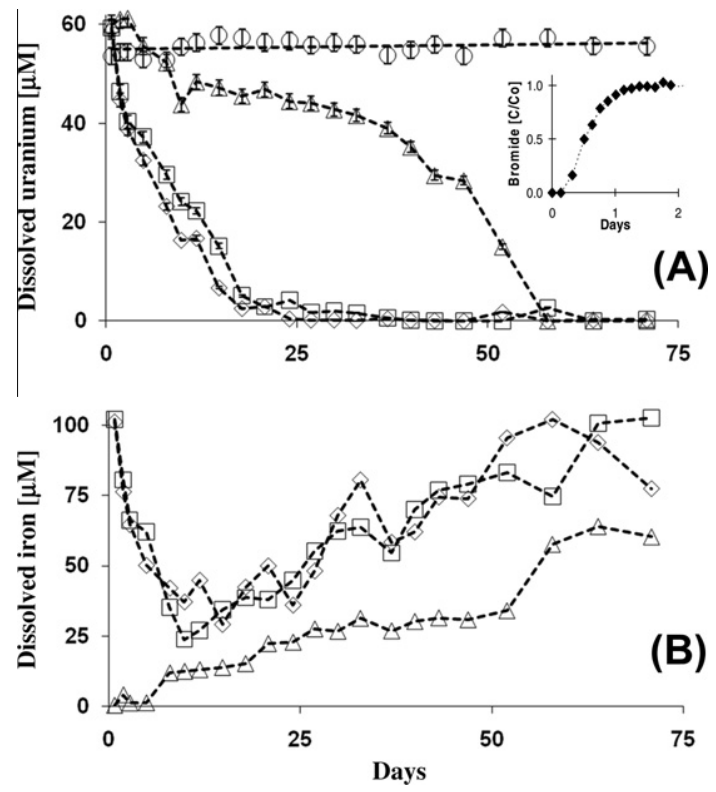

Fig. 1. Bioaugmented columns (A) remove $\mathrm{U}(\mathrm{VI})$ and (B) mobilize $\mathrm{Fe}(\mathrm{II})$. Where $O=$ influent concentration; $\diamond, \square=$ replicate columns augmented with active cells; $\triangle=$ cells deactivated in formaldehyde prior to introduction in the column. The inset depicts $\mathrm{Br}^{-}$ tracer breakthrough in a microbially active column.

Consistent with metal reduction, uranium removal was accompanied by the release of $\mathrm{Fe}(\mathrm{II})$ from the sediments (Fig. 1B). In the three columns, the onset of $98 \% \mathrm{U}$ removal correlated to an effluent concentration of $48 \pm 11 \mu \mathrm{M}$ $\mathrm{Fe}(\mathrm{II})$. The high $\mathrm{Fe}(\mathrm{II})$ values displayed in the first week and corresponding concave dip were related to a pulse of excess lactate during the conditioning phase (first 19 days not shown) of the experiment. Throughout the experiment, the concentration of carbonate $(30 \mathrm{mM})$ and $\mathrm{pH}$ of the influent $(7.5 \pm 0.2)$ and effluent $(7.6 \pm 0.2)$ were maintained. Consistent with microbial respiration, the introduced lactate was converted to acetate and another carboxylate presumed to be formate (Fig. EA-2).

Subsequent to bioreduction, column AC-2 was flushed with oxygenated, electron $\left(e^{-}\right)$donor- and uranium-free influent. Over the course of 64 days, dissolved iron was flushed from the column and oxygen breakthrough was not observed (not shown). A modest $\mathrm{pH}$ increase was recorded (influent $\mathrm{pH}=7.4 \pm 0.2$; effluent $\mathrm{pH}=7.8 \pm 0.1$ ). Although the uranium concentration in effluent samples revealed occasional pulses, mass balance analysis of sediment digests indicated negligible change in total uranium concentration as described in the next section.

\subsubsection{Uranium distribution and speciation in column sediments}

Chemical digestion by two complementary methods determined the bulk distribution and speciation of uranium in the sediments after removal of amended U(VI) from solution. Total uranium concentration using Aqua Regia digestion and quantification by ICP-MS was not differentiable from aggressive oxidation of sediments by persulfate/bicarbonate followed by KPA analysis (Table 1). As described in the methods, uranium speciation was determined by contrasting these oxic digestions with anoxic extractions assumed to release only soluble U(VI).

Despite considerable quantities of Fe(II) in the effluent, uranium species were not uniformly distributed throughout the columns. In fact, in both active columns (AC-2 was flushed with oxic influent as described above) reduced uranium dominated the inflow section of sediments while oxidized uranium was predominant in the outflow section. Bulk uranium content in the inflow fraction was more than twice that found in the other two fractions of the same column. In contrast to the two active columns, the deactivated column was dominated by U(VI) throughout with the highest proportion of $\mathrm{U}(\mathrm{IV})$ in the middle section of the column.

\subsubsection{Bacterial community analysis of bioreduced sediments}

Sediment columns sacrificed at different times $(11,35$, and 75 days) were used to identify dominant bacterial lineages. BLAST results for the 16S rRNA gene clone libraries derived from nucleic acids in sediments indicated that the majority of organisms belonged to the phylum Firmicutes irrespective of the sampling time (Fig. 2). Relatives of Geobacter were not detected in any of the major groups identified. Within Firmicutes, a relative of an uncultured bacterium clone $\mathrm{BVC} 03$ dominated the columns after 11 and 35 days; $\mathrm{BVC} 03$ has been implicated in anaerobic reductive dechlorination of vinyl chloride in an aquifer (GenBank accession DQ833299). A high BLAST score was also obtained with an uncultured bacterium clone A_Lac-3_40 from a Fe(III)-reducing enrichment (Hansel et al., 2008). The clonal sequences from the final 75 day extracts were related to Sporomusa aerivorans and Desulfosp-

\section{Table 1}

Uranium content and speciation in sediments obtained from three sections of the three columns.

\begin{tabular}{|c|c|c|c|}
\hline & Inflow & Middle & Outflow \\
\hline \multicolumn{4}{|c|}{ Active column (AC-1) (mmol U/kg sediment) } \\
\hline $\mathrm{U}(\mathrm{IV})$ & $0.92 \pm 0.09$ & $0.25 \pm 0.06$ & $0.10 \pm 0.02$ \\
\hline $\mathrm{U}(\mathrm{VI})$ & $0.08 \pm 0.05$ & $0.23 \pm 0.02$ & $0.33 \pm 0.02$ \\
\hline $\mathrm{U}_{\mathrm{T}}{ }^{*}$ & $1.00 \pm 0.08$ & $0.48 \pm 0.06$ & $0.43 \pm 0.01$ \\
\hline $\mathrm{U}_{\mathrm{T}}^{\#}$ & $1.06 \pm 0.05$ & $0.49 \pm 0.02$ & $0.42 \pm 0.04$ \\
\hline \multicolumn{4}{|c|}{ Active column (AC-2) (mmol U/kg sediment) } \\
\hline $\mathrm{U}(\mathrm{IV})$ & $1.21 \pm 0.11$ & $0.17 \pm 0.07$ & $0.19 \pm 0.11$ \\
\hline $\mathrm{U}(\mathrm{VI})$ & $0.00 \pm 0.00$ & $0.39 \pm 0.05$ & $0.42 \pm 0.06$ \\
\hline $\mathrm{U}_{\mathrm{T}}{ }^{*}$ & $1.21 \pm 0.11$ & $0.56 \pm 0.05$ & $0.61 \pm 0.09$ \\
\hline $\mathrm{U}_{\mathrm{T}}^{\#}$ & $1.34 \pm 0.09$ & $\mathrm{NM}$ & $\mathrm{NM}$ \\
\hline \multicolumn{4}{|c|}{ Deactivated column (DC) (mmol U/kg sediment) } \\
\hline U(IV) & $0.00 \pm 0.04$ & $0.15 \pm 0.06$ & $0.02 \pm 0.05$ \\
\hline $\mathrm{U}(\mathrm{VI})$ & $0.43 \pm 0.03$ & $0.24 \pm 0.04$ & $0.29 \pm 0.04$ \\
\hline $\mathrm{U}_{\mathrm{T}}{ }^{*}$ & $0.43 \pm 0.03$ & $0.39 \pm 0.04$ & $0.29 \pm 0.03$ \\
\hline $\mathrm{U}_{\mathrm{T}}^{\#}$ & $0.41 \pm 0.03$ & $0.38 \pm 0.03$ & $0.28 \pm 0.02$ \\
\hline
\end{tabular}

$\mathrm{NM}=$ not measured

$\mathrm{U}_{\mathrm{T}}{ }^{*}$ analyzed after oxic digestion with persulfate.

$\mathrm{U}_{\mathrm{T}}^{\#}$ independently determined after Aqua Regia digestion.

AC-2 was exposed to oxic influent for 64 days prior to analysis.

$\mathrm{U}_{\mathrm{T}}$ concentrations are greater than $\sim 0.02 \mathrm{mmol}_{\mathrm{T}} / \mathrm{kg}$ sediment measured in unamended RABS (K. Campbell, unpublished data). 


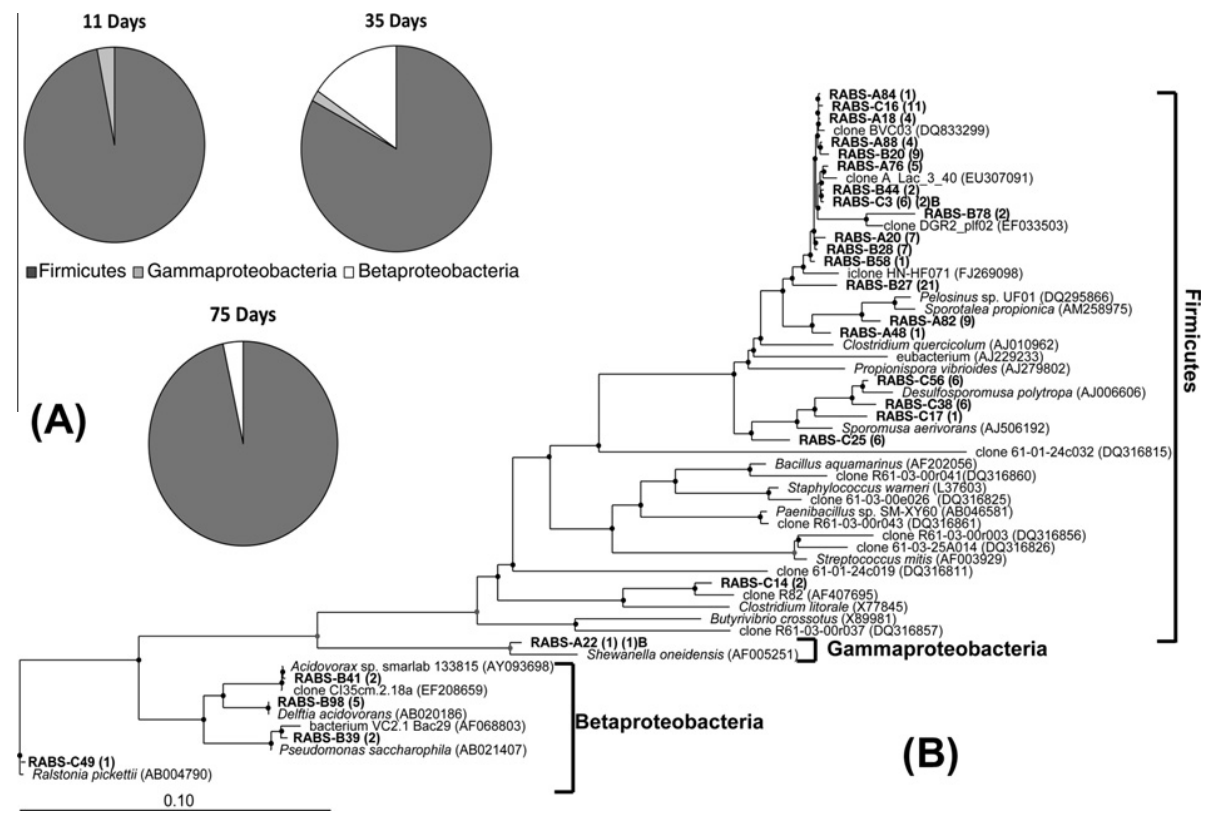

Fig. 2. Phylogenetic analysis of $16 \mathrm{~S}$ rRNA gene sequences cloned from sacrificial column sediments reveals dominance of Firmicutes. (A) Frequencies of bacterial phylogenetic lineages detected in the 16S rRNA gene clone libraries at 11, 35 and 75 days. (B) Phylogenetic tree with cloned PCR products indicated in bold and number of identical clones in brackets. The scale bar indicates 0.1 substitutions/site.

oromusa polytropha. The latter bacterium has been shown to grow autotrophically with $\mathrm{Fe}(\mathrm{OH})_{3}$ (Sass et al., 2004).

A temporal shift in community composition for non-Firmicutes bacteria was also observed. The majority of microorganisms outside of Firmicutes belonged to Gammaproteobacteria for the first time point (day 11). Though this class is consistent with our seeded inoculum, less than $3 \%$ of the clones belonged to the genus Shewanella. At the second time point (day 35), the community shifted from Gammaproteobacteria towards Betaproteobacteria as indicated by the presence of clones related to Acidovorax sp., Delftia acidovorans and Pseudomonas saccharophila. DNA extracted from the final column (day 75) revealed less diversity within Betaproteobacteria and a complete absence of Gamma-proteobacteria.

\subsection{Macro- and micro-scale XAS analyses of sediments}

\subsubsection{Bulk determination of uranium speciation and structure}

As sequentially described in this section, XAS analyses suggested that U(IV) associated with phosphoryl moieties dominated the immobilized sediments. To begin, XANES analysis indicated that the majority of the uranium in the influent portion of sediments was present as reduced U(IV) species (Fig. 3). Sample AC-2, which was subsequently exposed to 64 days of oxic water flushing had contributions from $26 \% \mathrm{U}(\mathrm{VI})$ while AC-1 was fully reduced within the detection limit $(10 \%)$. The XANES measurements for AC-1 are in agreement with the results of extractions and digestions to measure the contribution of $\mathrm{U}(\mathrm{VI})$, $\mathrm{U}(\mathrm{IV})$ and $\mathrm{U}_{\mathrm{T}}$ (Table 1). However, extractions and digestions revealed no evidence for U(VI) in sample AC-2. Collectively, this suggests heterogeneity in the distribution of $\mathrm{U}(\mathrm{VI})$ in AC-2 sediments, and this is supported by variabil-

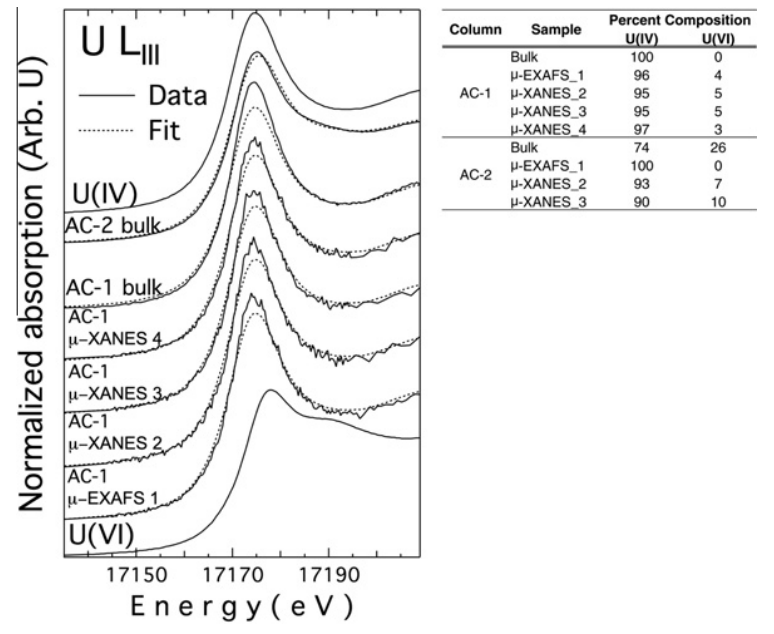

Fig. 3. XANES spectra and fits indicate a predominance of U(IV) in the inflow section of the columns at both bulk and micro-scales. Representative XANES spectra (solid line) with fit to data (dashed line). Percent composition is based upon best fit to spectra. U(IV) and $\mathrm{U}(\mathrm{VI})$ standards are reported in Schofield et al. (2008).

ity in microscopic-scale valence analyses. Specifically, a comparison of uranium valence in AC-2 for spot 1 and spot 3 versus AC- 1 for spots 1 through 4 underscores the more variable distribution in AC-2 (Fig. 3).

Approximate uranium loading of $1 \mathrm{mmol} \mathrm{U}$ per kg sediment $\left(\sim 250 \mathrm{mg} \mathrm{kg}^{-1}\right)$ in the influent section of the column was sufficient for bulk spectral U-EXAFS analysis to approximately $k=10 \AA^{-1}$ and revealed key details about local molecular structure around uranium (Fig. 4). Both column spectra lack a prominent $\mathrm{U}-\mathrm{U}$ pair correlation fre- 
quency at $3.85 \AA$ that is characteristic of biogenic uraninite (Sharp et al., 2009). Hence, while these sediments are dominated by U(IV), it is clear that uraninite is at most a minor species. Spectra show a prominent FT (Fourier Transform) magnitude at $1.5-1.8 \AA(r-\varphi)$, which is due to backscattering off of oxygen neighbors. Initial fits to the $\mathrm{O}$ shell using a single shell did not adequately reproduce experimental data. Fits to the AC-1 spectrum, which is dominated by $\mathrm{U}(\mathrm{IV})$, required two $\mathrm{O}$ shells, one at $2.41 \AA$ and another smaller shell at $2.23 \AA$ (Table 2). Addition of the second shell caused the statistical $\mathrm{R}$ factor to decrease by an order of magnitude (from 0.2 to 0.02 ) and is justified by the $\mathrm{U}(\mathrm{IV})-\mathrm{O}$ range of distances, $2.2-2.5 \AA$, encountered in $\mathrm{U}(\mathrm{IV})$ compounds such as $\mathrm{U}(\mathrm{OH})\left(\mathrm{PO}_{4}\right)$ and $\mathrm{U}(\mathrm{OH})_{8} \mathrm{P}_{4}$ (ICSD reference numbers 417158 and 66381). The presence of two shells explains the slightly square profile to the Oshell FT peak in this sample and is probably due to anharmonicity of the $\mathrm{U}-\mathrm{O}$ shell deriving from overlapping shells or non-Gaussian pair distribution functions. Sample AC-2 contained uranyl, corresponding to the peak at $1.5 \AA(r-$ $\varphi)$, necessitating the inclusion of an axial oxygen shell at $1.78 \AA$ in the fits.

A second FT peak is present in the spectra at ca. $2.7 \AA$ $(r-\varphi)$. This peak exhibits significant amplitude; in sample AC-1, it approaches half the height of the O-shell FT peak. Taking the longer radial distance into account (i.e., accounting for the greater $1 / r^{2}$ loss of signal), the height of the $2.7 \AA(r-\varphi)$ peak implies that it has a similar coordination number as the $\mathrm{O}$ shell if it is composed of elements with atomic number similar to oxygen such as $\mathrm{N}$ or $\mathrm{C}$. When this frequency was fit with $\mathrm{N}$ or $\mathrm{C}$, a distance of ca. $3.1 \AA$ was obtained, which would correspond to bidentate coordination of $\mathrm{U}$ to carboxyl groups (present in abundance on biomass and representing strong metal binding groups) or to nitrate (which is less abundant and a weaker metal-binding ligand), with coordination numbers of 6-8 atoms. However, since U(IV) is 8-coordinated by oxygen, and each $\mathrm{COO}^{-}$or $\mathrm{NO}_{3}{ }^{-}$group occupies two of these oxygen positions, it is possible to fit only four carboxylate or
Table 2

$\mathrm{U} \mathrm{L}_{\mathrm{II}}$-edge EXAFS fits (inflow section) for uranium removed from the dissolved phase.

\begin{tabular}{llll}
\hline & & AC-1 bulk & AC-2 bulk \\
\hline U-O1 & $N$ & - & $0.6 \pm 0.3$ \\
& $R(\AA)$ & - & $1.78(4)$ \\
& $\sigma^{2}\left(\AA^{2}\right)$ & - & 0.003 (fixed) \\
U-O2 & $N$ & $3.7 \pm 0.3$ & $4.2 \pm 1.0$ \\
& $R(\AA)$ & $2.23(2)$ & $2.19(6)$ \\
& $\sigma^{2}\left(\AA^{2}\right)$ & 0.003 (fixed) & 0.003 (fixed) \\
U-O3 & $N$ & $5.6 \pm 0.4$ & $5.2 \pm 1.2$ \\
& $R(\AA)$ & $2.41(2)$ & $2.38(5)$ \\
& $\sigma^{2}\left(\AA^{2}\right)$ & 0.003 (fixed) & 0.003 (fixed) \\
U-P & $N$ & $3.7 \pm 0.5$ & $2.7 \pm 0.8$ \\
& $R(\AA)$ & $3.22(3)$ & $3.22(7)$ \\
& $\sigma^{2}\left(\AA^{2}\right)$ & 0.010 (fixed) & 0.010 (fixed) \\
\hline
\end{tabular}

${ }^{a}$ Including multiple scattering contributions.

nitrate groups around each $\mathrm{U}$ atom. Thus, $\mathrm{C}$ or $\mathrm{N}$ neighbors are not consistent with the observed local molecular structure.

Phosphorus has approximately twice as many electrons as $\mathrm{C}$ or $\mathrm{N}$, resulting in stronger backscattering of photoelectrons. Consequently 3-4 P atoms can explain the results with good spectral fits using P neighbors at $3.22 \AA$ (Table 2 and Fig. 4). The derived U-P distance is consistent with bidentate coordination of $\mathrm{U}$ to phosphoryl groups; analogous binding conformations have been recently reported for U(IV) (Bernier-Latmani et al., 2010; Fletcher et al., 2010). This peak is at too long a distance to be attributable to an $\mathrm{O}$ shell, and too short a distance to be attributed to $\mathrm{Fe}$ or other transition metals, which are expected to occur at U-Me distances $>3.35 \AA$.

It is also possible, in principle, that the observed shell at $2.7 \AA(r-\varphi)$ is composed of $\mathrm{Si}$, which is abundant in the RABS mineralogy. However, the large amplitude of the peak (for which EXAFS fits produce 3-4 Si neighbors)
(A)

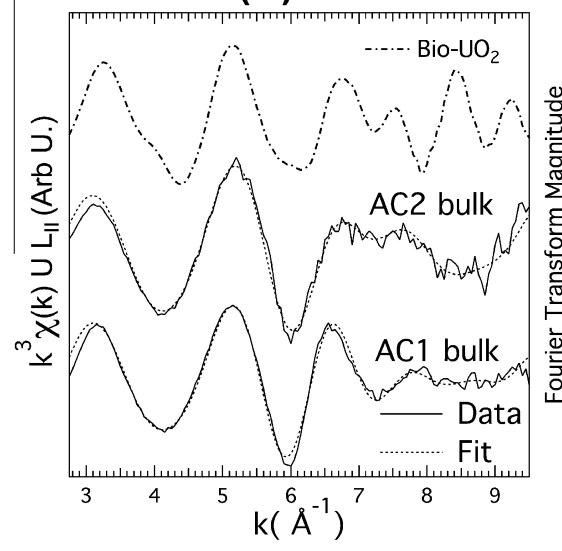

(B)

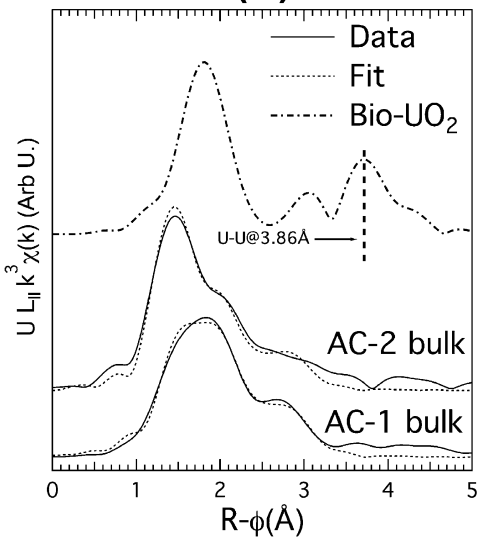

Fig. 4. EXAFS characterization of uranium associated with sediments is not representative of biogenic uraninite (A) U-EXAFS spectra (solid line) collected at $77 \mathrm{~K}$ with fit to data (dashed line) and (B) corresponding Fourier transform which depicts a presumed U-P shell at $\sim 2.8 \AA$. As shown in the reference biogenic uraninite spectrum, a prominent FT U-U shell at $3.86 \AA$ (Sharp et al., 2009) is not found in these sediments. 
is inconsistent with bidentate coordination of $\mathrm{U}(\mathrm{IV})$ to silicate surfaces where a coordination number of 1 would be expected (Sylwester et al., 2000). Coffinite $\left(\mathrm{USiO}_{4}\right)$ can be ruled out as a significant phase; it should exhibit $4 \mathrm{U}$ atomic neighbors at $3.83 \AA$ (not observed). EXAFS comparing both biogenic and chemogenic $\mathrm{UO}_{2}$ to coffinite are provided in Fig. EA-3 for further visual interpretation of these differences and to demonstrate that the collected data range is sufficient for analyses. Interpretation of the $2.7 \AA(r-\varphi)$ peak as sulfhydryl groups cannot be justified in our system, as insufficient sulfur was introduced through the influent, seeded biomass, or sediments (as determined by digestions and mass balance calculations). Therefore, the most plausible explanation for the results is binding of $\mathrm{U}(\mathrm{IV})$ to phosphate groups on the surfaces of minerals or biomass. This conclusion is consistent with experimental conditions present in the columns. Trimetaphosphate was added to the influent as a bioavailable source that would avoid the precipitation of calcium and uranium phosphates (Abdelouas et al., 1998). While we can rule out the precipitation of uranium with TMP, sediment digests revealed $\sim 20$ moles of phosphorus for every mole of uranium.

\subsubsection{Distribution of uranium within sediments: micro-scale analysis}

Combined micro-XRF and micro-XAS enables the spatial visualization of metals, their redox state, and mineral forms in solids by collecting spectra at each pixel to raster distribution and speciation (Pickering et al., 2000, 2006; Templeton et al., 2009). Micro-scale analyses of 2D thin-sections of sediments derived from the inflow section of AC-1 and AC-2 were conducted to characterize regions of uranium accumulation. As shown in a sample derived from AC-2, contrast of the overall X-ray density with elemental signatures revealed uranium heterogeneities associated with sediments. Sifted RABS are dominated by quartz and feldspar with lesser amounts of amphiboles and clays (Campbell et al., 2011). Fig. 5A depicts a number of sediment grains to provide a visual interpretation of uranium versus iron locality. The inset focuses on one of these grains, possibly quartz, with minimal iron density. Further elemental analysis demonstrated that the grain was also devoid of other elemental signatures such as $\mathrm{K}$ or $\mathrm{Ca}$ that would be found in clays. In addition, U(IV) dominated the uranium hot spots with an insignificant contribution of diffuse U(VI) throughout the sediments (Figs. 5A inset; B). While certain localities that were high in iron were also high in uranium, correlation plots on this sample and others and visual interpretation did not reveal a clear association between uranium and iron localization (Figs. 5A-C and EA-4). Collectively, these results indicate that iron proximity, as resolved at the micrometer scale, is not a driving factor for U(IV) immobilization.

Micro-XAS analysis of these uranium hot spots was used to further characterize the reduced uranium zones, and XANES analysis confirmed that U(IV) was the dominant species (Fig. 3). While the data range of the $\mu$-EXAFS was not sufficient for detailed fits, a spectral overlay of bulk and $\mu$-EXAFS shows that they are qualitatively similar up to $c a$. $6.5 \AA^{-1}$ (Fig. 5D). This range is sufficient to conclude that the $\mathrm{O}$ shells are similar in the micro and bulk data points.

\subsection{Stability of uranium in sediments after immobilization}

While the addition of oxic, bicarbonate-containing water to the column resulted in localized oxidation, it did not succeed in mobilizing a significant fraction of $U$ in the sediments nor was oxygen breakthrough observed in the effluent (see Section 3.1.1). We turned to a continuous-flow stirred tank reactor (CFR) to further investigate the stability and mobility of uranium in sediments derived from the inflow section of AC-1. The flow-through release of dissolved uranium under oxidizing conditions in the presence of $30 \mathrm{mM}$ dissolved inorganic carbon (DIC) was measured as a function of time. As shown in Fig. 6a, after the initiation of flow to the reactors $(t=0)$, the effluent $\mathrm{U}$ concentrations quickly peaked at a maximum of $\sim 2 \mu \mathrm{M}$ in both reactors, and then rapidly decreased with time.

Mathematical fits to interpret these trends were based on the presence of uranium in single or multiple pools which each had different rates of uranium release (Ulrich et al., 2009). The best match to the experimental data was obtained for calculations assuming two pools of solid $U$ phases releasing $U$ simultaneously at two different rates. According to the results of a least-squares minimization routine applied separately to the data sets of both replicate CFRs before averaging, a first order rate constant of $47.3 \pm 4.8 \mathrm{~h}^{-1}$ referred to release from a pool of initially $29 \%$ of total $\mathrm{U}$, whereas the other $71 \%$ of the total $\mathrm{U}$ exhibited a first order rate constant of $0.70 \pm 0.07 \mathrm{~h}^{-1}$. This corresponded to uranium-normalized release rates for the two U-pools of $(5.5 \pm 0.6) \cdot 10^{-5} \mathrm{~mol}\left(\mathrm{~g} \mathrm{U}^{-1} \mathrm{~s}^{-1}\right.$ and $(8.1 \pm 0.9) \cdot 10^{-7} \mathrm{~mol}(\mathrm{~g} \mathrm{U})^{-1} \mathrm{~s}^{-1}$. Two pools of $\mathrm{U}$ with different release rates were required to fit the data; calculations based on a single pool of solid-phase uranium provided poor fits to the time-dependent $U$ release data.

A second dissolution experiment utilized a sequence to explore the dependence of U release rates on DIC and oxygen concentration. This started with DIC-free anoxic feed solution where after approximately $10 \tau$, the effluent uranium concentration ([U] $\left.]_{\mathrm{eff}}\right)$ reached a steady-state concentration that corresponded to a release rate from the sediment of $1.4 \cdot 10^{-8} \mathrm{~mol}(\mathrm{~g} \mathrm{U})^{-1} \mathrm{~s}^{-1}$ (Fig. 6b). After spiking $1 \mathrm{mM}$ DIC to the feed solution in the presence of $\sim 1 \%$ $p \mathrm{O}_{2}$ headspace, a pulse release of uranium with a peak concentration of $>1 \mu \mathrm{M}$ was observed. Beyond this peak, $[\mathrm{U}]_{\mathrm{eff}}$ diminished with time without reaching a steady-state within $35 \tau$, suggesting a continued decrease of the release rate. Therefore, only an order of magnitude $\left(1 \cdot 10^{-7} \mathrm{~mol}(\mathrm{~g} \mathrm{U})^{-1} \mathrm{~s}^{-1}\right)$ can be estimated for the $\mathrm{U}$ release rate. After switching the feed solution to $21 \%$ headspace $p \mathrm{O}_{2}$, the reactor's effluent responded with a modest pulse release of uranium before the dissolution rate continued to decrease, suggesting that oxidizable U(IV) was nearly exhausted. 


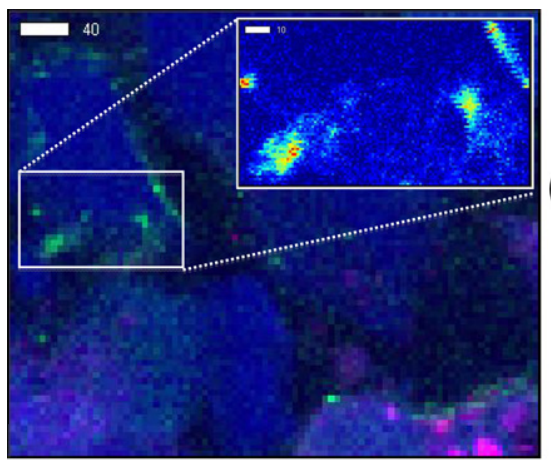

(A)

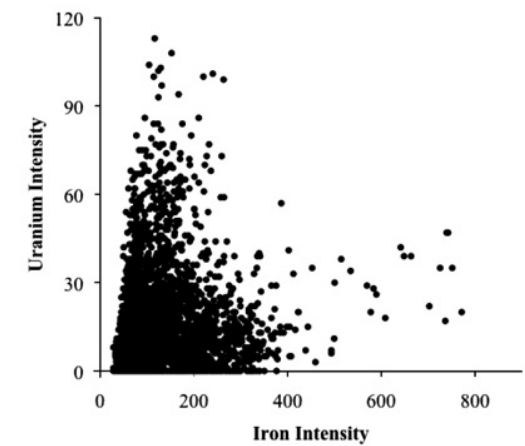

(C)
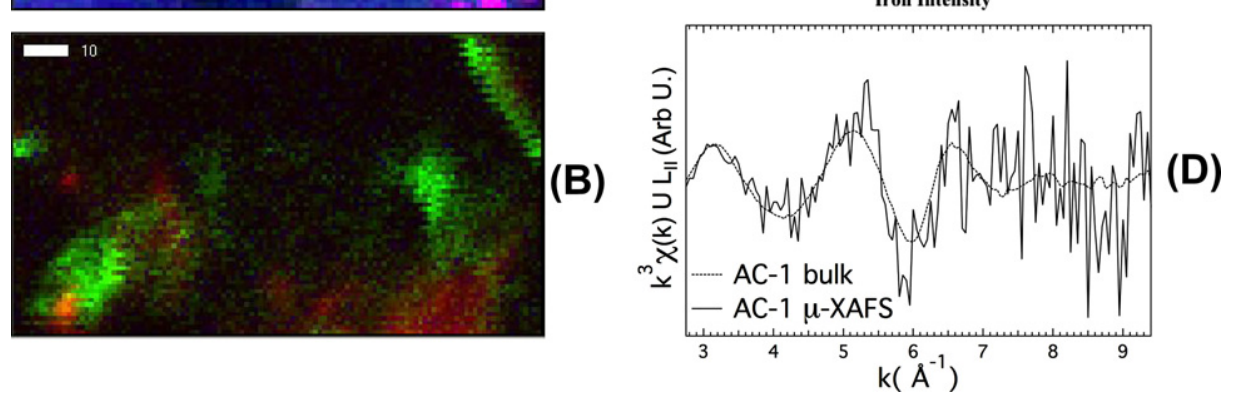

Fig. 5. Micro-XAS/XRF analysis of uranium micro heterogeneities in column sediment 2D thin-sections. (A) Overall tri-color map of region showing $\mathrm{Fe}_{\mathrm{T}}=$ red, $\mathrm{U}_{\mathrm{T}}=$ green, sample absorption = blue. Inset shows high-resolution area of interest with uranium heterogeneities as a heat plot of concentration. (B) Localization of $\mathrm{U}(\mathrm{IV})=$ green, $\mathrm{U}(\mathrm{VI})=$ blue, and $\mathrm{Fe}_{\mathrm{T}}=$ red. Intensities of $\mathrm{U}$ oxidation state were determined by fitting multiple energy maps to appropriate $U$ standards at each pixel. Fe intensity from the fluorescent counts was determined at $E=17,100 \mathrm{eV}$. Fluorescence of $\mathrm{U}$ and Fe were scaled separately and $\mathrm{U}(\mathrm{IV})$ and $\mathrm{U}(\mathrm{VI})$ equally from 0 to the maximum fluorescence of $\mathrm{U}$ from the sample. (C) Correlation plot of $\mathrm{U}$ and Fe intensities at each pixel in the image map. The plot shows that in the locations of high $\mathrm{U}$, there is very little Fe present, and in locations of high Fe, only low to background concentrations of U. (D) Overlay of $\mu$-EXAFS spectrum for a $\mathrm{U}(\mathrm{IV})$ hot spot with the bulk EXAFS spectrum. All scale bars are in micrometers.

(A)

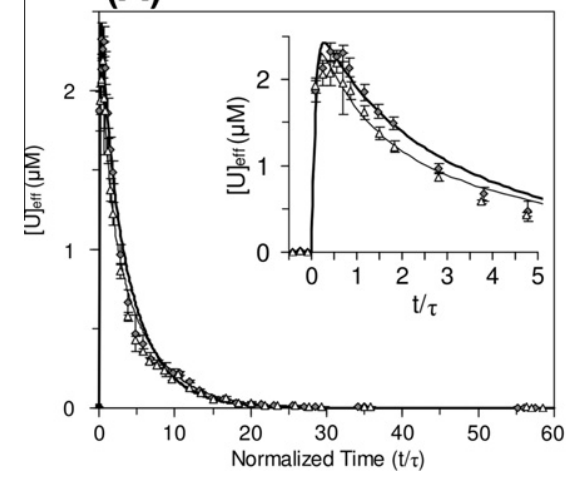

(B)

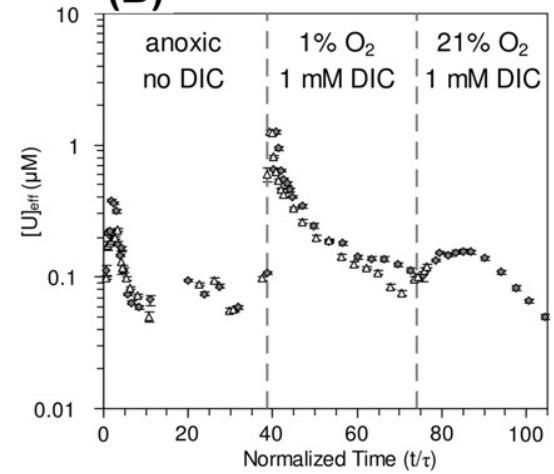

Fig. 6. Flow-through release of uranium from bioreduced $\mathrm{AC}-1$ sediment in the presence of (A) solution equilibrated under oxic conditions (atmospheric $p \mathrm{O}_{2}$ ) and $30 \mathrm{mM}$ DIC, (B) a sequence of solutions transitioning from anoxic conditions without DIC to $1 \mathrm{mM}$ DIC and atmospheres of $1 \% p \mathrm{O}_{2}$ and $21 \% \mathrm{pO}_{2}$. Symbols show effluent concentrations of dissolved $\mathrm{U}$ of two replicate reactors as a function of normalized time, which is the cumulative reaction time $(t)$ divided by the reactor hydraulic residence time $(\tau)$. Error bars reflecting one standard deviation of analysis are mostly smaller than the symbol size. The lines in (A) show the modeled effluent concentration assuming $\mathrm{U}$ release from two U pools at different rates. The inset enlarges the first five residence times. The vertical dashed lines in (B) indicate the time of condition switch. Note the differently scaled $y$-axes.

\section{DISCUSSION}

Column experiments were designed to study both the structure and stability of bioreduced uranium in sediments.
While uranyl concentrations and flow rates were higher than those encountered at contaminated sites, laboratory conditions enabled sufficient $U$ loading to more accurately explore the sediment system. Micro- and macro-scale XAS 
analyses were complemented by explorations into bacterial phylogeny, uranium species distribution, and stability of uranium retained in the investigated sediments.

\subsection{Structure and distribution in sediments}

The bioaugmented columns were reproducible with regards to uranium sequestration with both microbially active and formaldehyde-treated columns achieving sustained removal of $55 \pm 2 \mu \mathrm{M}$ influent uranyl (Fig. 1). In both active columns, $\mathrm{U}_{\mathrm{T}}$ uptake and $\mathrm{U}(\mathrm{IV}): \mathrm{U}_{\mathrm{T}}$ ratios were highest in the inflow section (Table 1) which is consistent with a flow reactor and prior reports in an analogous Geobacteramended column (Moon et al., 2007). No sulfate was added to the influent in order to limit competition with iron reduction. Additional evidence for dissimilatory metal reduction included oxygen removal, conversion of lactate to fatty acid metabolites, and the reduction of solid-associated Fe(III). The formation of dissolved $\mathrm{Fe}(\mathrm{II})$ in the effluent of all three columns provided a parallel indicator of optimal uranium immobilization.

The dominant microbes observed during subsurface reductive immobilization vary; however, Shewanella's tolerance for oxygen (facultative anaerobe) and preference for lactate, coupled to the recent observation of conserved uraninite products formed by genera such as Shewanella and Geobacter (Sharp et al., 2009), focused column design parameters. While not the focus of past field uranium immobilization studies, lactate has a possible advantage over acetate in that it may support sulfate reducing communities that are also capable of reducing U(VI) (Anderson et al., 2003).

Surprisingly, 16S rRNA gene sequences obtained from the sediments in our current study demonstrated that even before complete uranium immobilization was achieved, the seed community of $S$. oneidensis accounted for only 3 out of 120 clones, and was only detected in the first sampling event (Fig. 2). Prior column work has emphasized the need for bioaugmentation in laboratory experiments ( $\mathrm{Gu}$ et al., 2005; Moon et al., 2007); however, this rapid Shewanella die-off coupled to the observation of complete immobilization, albeit after more time when deactivated cells were added (DC column in Fig. 1), suggests that the primary role of the seed community was in facilitating reducing conditions and/or providing nutrients to the indigenous metalreducing Firmicutes. Spore-forming, Gram-positive bacteria such as Firmicutes can, and clearly did, survive in dry sifted RABS, and species from this phylum have been shown to reduce uranium (Junier et al., 2009; Bernier-Latmani et al., 2010). Furthermore, the presence of Firmicutes has been documented in other studies investigating microbial assemblages in uranium contaminated sites (Akob et al., 2007) and sediment enrichments from the Oak Ridge (ORFRC) Field Research Center (Madden et al., 2007). In a separate laboratory study, Firmicutes appeared as a dominant lineage subsequent to acetate biostimulation in RABS (N'Guessan et al., 2008). The post-acetate amendment phase was accompanied by increased U(VI) sorption in those columns. Strikingly, U(VI) sorption in lieu of reduction also took place in the effluent section of our columns in which minimal microbial activity would be expected if the $e^{-}$donor is consumed earlier in the columns. The Firmicutes detected in our biostimulated RABS were only distantly related to clones from the ORFRC, suggesting a wide distribution of Firmicutes clades at prominent uranium-contaminated sites.

Our experimental objectives necessitated higher $\mathrm{U}_{(\mathrm{aq})}$ concentrations than typical of contaminated aquifers, which could impact uranium sorption and complexation. However, our preliminary observations during acetate biostimulation at the Old Rifle Site suggest that higher U concentrations such as those used here bias towards increased precipitation of uraninite. In contrast, bulk XAS analyses conducted in the current study revealed that while the columns were dominated by U(IV), the reduced uranium was not in the form of uraninite, but rather was associated with low-Z ligands, most likely phosphoryl groups (Figs. 3 and 4, and Table 2). Interestingly, the association of uranium(IV) with phosphoryl groups has also been postulated for liquid batch incubations of Desulfotomaculum spores, biogenic Fe(II)-bearing iron phosphates, Desulfitobacterium spp., Cellulomonas sp. and even $S$. oneidensis $\mathrm{sp}$. incubated in the presence of higher ionic strength media (Bernier-Latmani et al., 2010; Fletcher et al., 2010; Ray et al., 2011; Sivaswamy et al., 2011; Veeramani et al., 2011). Ningyoite, a Ca-U(IV)-phosphate precipitate, has also been observed during $U$ reduction in pure cultures (Bernier-Latmani et al., 2010; Lee et al., 2010). In contrast, an 11-month static microcosm study of sediment from the Oak Ridge IFRC that included DMRB and DSRB revealed that U(IV) was found as both uraninite and in association with $\mathrm{Fe}$ groups at the surface of $\mathrm{Fe}$ oxide minerals (Kelly et al., 2010). The association of U(IV) with phosphoryl groups as a result of pure culture batch biological U(VI) reduction seems to carry over into the present sediment setting. This observation points to the fact that the speciation of U(IV) resulting from combined biologic and abiotic processes in sediments is more complex and varied than previously appreciated and appears to depend primarily on the geochemical conditions under which reduction occurs.

The XAS signature for locally concentrated regions of $\mathrm{U}(\mathrm{IV})$ observed at the micro-scale is similar to that characterized for bulk sediments; this enables further inference (Fig. 5). In principle, U(IV) hot spots could be explained by contributions from both abiotic and biological reductive processes. Iron makes up almost 3\% (533 $\left.\pm 12 \mathrm{mmol} \mathrm{kg}^{-1}\right)$ of RABS by weight, and a detailed analysis of iron distribution and speciation in analogous DMRB columns has revealed that $20-40 \%$ of produced $\mathrm{Fe}$ (II) is released into the effluent while much of the remainder is associated with iron oxides and clays (Komlos et al., 2008b). Iron associated with clays, oxides, and sulfides could be involved in uranium redox transformations and immobilization (Abdelouas et al., 1999; Komlos et al., 2008b; Tokunaga et al., 2008). Similarly, sorption of U(VI) onto Fe(II) minerals followed by reduction could account for the formation of nonuraninite U(IV) (Jang et al., 2008; O'Loughlin et al., 2010; Veeramani et al., 2011).

However, as seen in Fig. 5 and the related results, uranium precipitation on sediment grains did not correlate 
with iron localities. The EXAFS spectra of the present samples, particularly AC-1, exhibit a structural $\mathrm{P}$ shell at $3.2 \AA$, believed to be characteristic of enzymatically reduced, biomass-associated monomeric U(IV) (BernierLatmani et al., 2010). Moreover, these spectra also lack the U-Fe pair correlation indicative of association of $\mathrm{U}(\mathrm{IV})$ with Fe minerals that may result from Fe(II)-mediated abiotic U(VI) reduction. Hence, our results imply that direct enzymatic reduction rather than Fe(II)-mediated processes are responsible for $\mathrm{U}$ immobilization in this sediment column experiment.

The presence of retained U(VI), particularly in the case of the deactivated biomass (DC) column and the outflow sections of the two active columns (Table 1), can be rationalized as sorption of $\mathrm{U}(\mathrm{VI})$ onto sediment minerals or biomass; alternatively it could be the result of oxidation of reduced U(IV) (Tokunaga et al., 2008) or suggest a lower abundance of $\mathrm{U}(\mathrm{VI})$ reducing microbes due to upstream consumption of lactate. Regardless, sediment association was sufficiently strong to overcome complexes with $30 \mathrm{mM} \mathrm{HCO}_{3}{ }^{-}$. While this carbonate concentration exceeds that expected in the subsurface, it was selected to maximize the potential for immobilization of $U(I V)$ versus $\mathrm{U}(\mathrm{VI})$ in our columns as $\mathrm{U}(\mathrm{VI})$-carbonato complexes are known to limit sorption (Wazne et al., 2003). Given this experimental bias, the degree of immobilized U(VI) was unexpected and can be anticipated to be even greater in the presence of lower bicarbonate concentrations. In a recent report investigating DMRB sediment columns, U(VI) sorption was found to be the primary immobilization mechanism following the termination of acetate additions; Firmicutes dominated the system at that time (N'Guessan et al., 2008). U(VI) has also been reported to strongly sorb to clays and iron oxyhydroxides in both laboratory and environmental systems (Payne et al., 1994; Bargar et al., 1999; Catalano and Brown, 2005; Catalano et al., 2006).

\subsection{Stability of immobilized uranium}

Chemical digests and in situ stability tests suggest that uranium content and distribution in a column subsequently exposed to oxic influent for 64 days was similar to a column immediately harvested after the active U-uptake phase (Table 1). While bulk XAS analysis indicated modest reoxidation, micro-XAS confirmed that localized regions of U(IV) were still present. Oxygen in these columns can be consumed by many processes in addition to U(IV) oxidation. The observation of oxygen breakthrough in analogous Geobacter-stimulated columns after one month (Moon et al., 2007) suggests that stronger oxygen buffering is influenced by higher $e^{-}$donor availability $(15 \mathrm{mM}$ lactate in our system versus $3 \mathrm{mM}$ acetate used by Moon and collaborators) as well as more initial biomass added as the seeded S. oneidensis community. Bulk protein or organic quantification was not conducted in either study.

Uranium stability was investigated ex situ using flowthrough experiments. These experiments use a higher ratio of water to sediment than in the columns or subsurface, and this higher ratio can result in more rapid mobilization and/ or oxidation. Thus, the flow-through experiments enable release rate measurements, the identification of different pools of U(IV), and comparison to prior laboratory results. The experimental results demonstrate that a reaction of sediments derived from the inflow section of AC-1 with airequilibrated, $1 \mathrm{mM}$ DIC solution led to extensive remobilization of uranium. Remobilization was best described by two different dissolution rates corresponding to two separate mobilization processes. For example, desorption of $\mathrm{U}(\mathrm{VI})$ and oxidation of $\mathrm{U}(\mathrm{IV})$ would point to two different U-pools. Another possibility for two release rates could be mobilization of two different U(IV) species, such as desorption of molecular U(IV) (Bernier-Latmani et al., 2010) and oxidation of a more stable $\mathrm{UO}_{2}$ solid phase. A third possibility would be a combination of the first two, where the release rates from two U-pools or by two mobilization mechanisms were too similar to be discriminated by our experiment. Although the exact nature of the U pools cannot be discerned from these experiments, complementary digestions and structural analyses showed that the fraction of $\mathrm{U}(\mathrm{VI})$ in the inflow section of the column was very small, suggesting that two different forms of U(IV) with different physical release mechanisms or oxidation rates existed. This is most likely explained by two or more non- $\mathrm{UO}_{2} \mathrm{U}(\mathrm{IV})$ species because XAS data suggest the absence of significant $\mathrm{UO}_{2}$ in the sediment. Empirical observations during sample handling indicate that a fraction of the U(IV) associated with the sediments is very reactive with $\mathrm{O}_{2}$ which is consistent with the CFR results.

The sediments demonstrated a dependency of the oxidation rate on both the $p \mathrm{O}_{2}(1$ versus $21 \%$ vol) and DIC concentration (1 versus $30 \mathrm{mM}$ ) (Fig. 6). Specifically, release rates of the less labile phase from the sediments in the presence of DIC and $\mathrm{O}_{2}$ were more than an order of magnitude higher than in the absence of DIC and $\mathrm{O}_{2}$. Furthermore, release rates of $8.1 \cdot 10^{-7} \mathrm{~mol} \mathrm{~g}^{-1} \mathrm{~s}^{-1}$ for the less labile, predominant U-phase in $21 \% \mathrm{O}_{2}$ and $30 \mathrm{mM}$ DIC were 4-times higher than for biogenic $\mathrm{UO}_{2}(\mathrm{~s})$ under similar experimental conditions (Ulrich et al., 2009). U release from the bioreduced sediment under reducing and DIC-free conditions resulted in a $[\mathrm{U}]_{\mathrm{eff}}$ level (Fig. 6b) that was 10 to 100-times higher than for isolated, cleaned biogenic $\mathrm{UO}_{2}$ nanosolids under similar flow-through conditions (Ulrich et al., 2008). The corresponding calculated $U$ release rates from the sediment of $1.4 \cdot 10^{-8} \mathrm{~mol}(\mathrm{~g} \mathrm{U})^{-1} \mathrm{~s}^{-1}$ were 5 orders of magnitude higher than for biogenic $\mathrm{UO}_{2}(\mathrm{~s})$ dissolution (e.g., $5.3 \cdot 10^{-13} \mathrm{~mol} \mathrm{~g}^{-1} \mathrm{~s}^{-1}$ ) (Ulrich et al., 2008). However, these calculated release rates include the effects of chemical reactions and physical transport processes such as diffusion of oxygen and DIC into micropores of the bulk sediment and diffusion of desorbed U(IV) or oxidized U(VI) out of such pores, and hence represent an upper bound for uranium mobility at a solids concentration of roughly $8 \mathrm{~g} \mathrm{~L}^{-1}$. Irrespective of the particular processes driving U-release, we can conclude that the U(IV) species obtained from bioreduction in sediments $(250 \mathrm{mg} \mathrm{U}$ (kg sediment $)^{-1}$ ) are less stable under both anoxic and oxic conditions than are cleaned biogenic $\mathrm{UO}_{2}$ solids (Ulrich et al., 2008, 2009). 


\section{CONCLUSION}

Coupled reductive and sorptive processes are considered favorable for overall uranium sequestration (Fredrickson et al., 2000). At the same time, retained uranium species vary in their stability and distribution, which could alter their potential mobility. Hence, both the mechanisms and forms of uranium immobilized by a bioremediation strategy have implications for determining which processes are most relevant for improving subsurface uranium stability. While lactate biostimulation led to a rapid shift in the augmented microbial community from seeded Shewanella sp. to indigenous Firmicutes, this and other recent reports (Bernier-Latmani et al., 2010; Fletcher et al., 2010; Lee et al., 2010; Sivaswamy et al., 2011; Veeramani et al., 2011) suggest that the geochemical environment may play a greater role in influencing U(IV) products than does biological variability. It remains unclear whether this is due to purely chemical effects such as complexation and solute competition or rather to geochemical influences on microbial processes such as the production of exudates.

However, the role of microorganisms during uranium reduction in sediments should not be dismissed. The local structure around U(IV) in our uranium-immobilized sediments (Fig. 4) resembles that associated with a suite of axenic bacterial assays where enzymatically reduced monomeric U(IV) coordination complexes were bound to $\mathrm{P} / \mathrm{C}$-containing ligands in biomass (Bernier-Latmani et al., 2010). This supports the conclusion that U(IV) in our immobilized sediments was also associated with biomass. Evidence for indirect reduction by biogenic iron oxides was not found; specifically, a U-Fe pair correlation indicative of association of $\mathrm{U}(\mathrm{IV})$ with $\mathrm{Fe}$ minerals was not observed at the micrometer scale (Fig. 5). Hence it appears that direct enzymatic pathways, rather than abiotic reduction by $\mathrm{Fe}(\mathrm{II})$ at mineral surfaces, were the primary mechanism for uranium reduction in these sediments.

Prior work has focused on $\mathrm{UO}_{2}$ as the presumed product of uranium bioreduction and has demonstrated that different bacteria can produce similar and stable nanocrystals (Burgos et al., 2008; Schofield et al., 2008; Sharp et al., 2009). Conservation of $\mathrm{UO}_{2}$ precipitates and the ability of genera such as Shewanella to form both $\mathrm{UO}_{2}$ and other $\mathrm{U}(\mathrm{IV})$ species suggest that a specific bacterial identity is unlikely to be the driving force (Sharp et al., 2009; Bernier-Latmani et al., 2010). Here we report that during and after biologically-mediated uranium reduction in sediments, U(IV) species in association with low-Z ligands, probably phosphoryl groups on biomass, can be dominant products. While this immobilized U(IV) can be released more rapidly than $\mathrm{UO}_{2}$, the high solid-water ratios in the columns and subsurface may enhance the long-term sequestration of uranium. The formation mechanisms and stability of these species need to be further explored before we can predict the efficacy of subsurface remediation scenarios as well as better understand the uranium biogeochemical cycle.

\section{ACKNOWLEDGMENTS}

Work carried out at EPFL was funded by the U.S. Department of Energy (DOE) OBER Grant No. DE-FG02-06ER64227, Swiss NSF Grant No. 20021-113784, and SNSF International Co-operation Grant No. IZK0Z2-12355. Work at CSM was supported by the Office of Science (BER) U.S. Department of Energy. Work at WUSTL was partially supported by the DOE (Grant DE-FG0206ER64227). Portions of this research were carried out at the Stanford Synchrotron Radiation Lightsource, a national user facility operated by Stanford University on behalf of the DOE, Office of Basic Energy Sciences and supported by the SSRL Environmental Remediation Science Program and BER-ERSD Project No. SCW0041. The SSRL Structural Molecular Biology Program is supported by the Department of Energy, Office of Biological and Environmental Research, and by the National Institutes of Health, National Center for Research Resources, Biomedical Technology Program.

We thank John Komlos for advice in designing column experiments, Aaron Peacock, Ken Williams, Philip E. Long and Richard Dayvault for supplying RABS, Dominique Grandjean for elemental sulfur analysis, Jean-David Teuscher for organic analysis of sediments, Jean-Pierre Kradolfer for contributions to column construction, and Lisa Blue for sediment digestions and associated analyses. We also thank Christopher Kim, Thomas Borch, and two anonymous referees for reviews of an earlier version of this manuscript.

\section{APPENDIX A. SUPPLEMENTARY DATA}

Supplementary data associated with this article can be found, in the online version, at doi:10.1016/ j.gca.2011.08.022.

\section{REFERENCES}

Abdelouas A., Lu Y. M., Lutze W. and Nuttall H. E. (1998) Reduction of $\mathrm{U}(\mathrm{VI})$ to $\mathrm{U}(\mathrm{IV})$ by indigenous bacteria in contaminated ground water. J. Contam. Hydrol. 35(1-3), 217233.

Abdelouas A., Lutze W. and Nuttall H. E. (1999) Oxidative dissolution of uraninite precipitated on Navajo sandstone. $J$. Contam. Hydrol. 36(3-4), 353-375.

Akob D. M., Mills H. J. and Kostka J. E. (2007) Metabolically active microbial communities in uranium-contaminated subsurface sediments. FEMS Microbiol. Ecol. 59(1), 95-107.

Anderson R. T., Vrionis H. A., Ortiz-Bernad I., Resch C. T., Long P. E., Dayvault R., Karp K., Marutzky S., Metzler D. R. and Peacock A., et al. (2003) Stimulating the in situ activity of Geobacter species to remove uranium from the groundwater of a uranium-contaminated aquifer. Appl. Environ. Microbiol. 69(10), 5884-5891.

Bargar J. R., Reitmeyer R. and Davis J. A. (1999) Spectroscopic confirmation of uranium (VI) adsorption complexes on hematite. Environ. Sci. Technol. 33(14), 2481-2484.

Bernier-Latmani R., Veeramani H., Vecchia E. D., Junier P., Lezama-Pacheco J. S., Suvorova E. I., Sharp J. O., Wigginton N. S. and Bargar J. R. (2010) Non-uraninite products of microbial U(VI) reduction. Environ. Sci. Technol. 44(24), 94569462.

Burgos W. D., McDonough J. T., Senko J. M., Zhang G., Dohnalkova A. C., Kelly S. D., Gorby Y. A. and Kemner K. M. (2008) Characterization of uraninite nanoparticles produced 
by Shewanella oneidensis MR-1. Geochim. Cosmochim. Acta 72(20), 4901-4915.

Campbell K. M., Davis J. A., Bargar J., Giammar D., BernierLatmani R., Kukkadapu R., Williams K., Veeramani H., Ulrich K.-U. and Stubbs J., et al. (2011) Composition, stability, and measurement of reduced uranium phases for groundwater bioremediation at Old Rifle, CO. Appl. Geochem. 26, S163S169.

Catalano J. G. and Brown G. E. (2005) Uranyl adsorption onto montmorillonite: evaluation of binding sites and carbonate complexation. Geochim. Cosmochim. Acta 69(12), 2995-3005.

Catalano J. G., McKinley J. P., Zachara J. M., Heald S. M., Smith S. C. and Brown G. E. (2006) Changes in uranium speciation through a depth sequence of contaminated Hanford sediments. Environ. Sci. Technol. 40(8), 2517-2524.

Fletcher K. E., Boyanov M. I., Thomas S. H., Wu Q. Z., Kemner K. M. and Loffler F. E. (2010) U(VI) Reduction to mononuclear U(IV) by Desulfitobacterium species. Environ. Sci. Technol. 44(12), 4705-4709.

Fredrickson J. K., Zachara J. M., Kennedy D. W., Duff M. C., Gorby Y. A., Li S. M. W. and Krupka K. M. (2000) Reduction of $\mathrm{U}(\mathrm{VI})$ in goethite (alpha-FeOOH) suspensions by a dissimilatory metal-reducing bacterium. Geochim. Cosmochim. Acta 64(18), 3085-3098.

Gu B. H., Wu W. M., Ginder-Vogel M. A., Yan H., Fields M. W., Zhou J., Fendorf S., Criddle C. S. and Jardine P. M. (2005) Bioreduction of uranium in a contaminated soil column. Environ. Sci. Technol. 39(13), 4841-4847.

Hansel C. M., Fendorf S., Jardine P. M. and Francis C. A. (2008) Changes in bacterial and archaeal community structure and functional diversity along a geochemically variable soil profile. Appl. Environ. Microbiol. 74(5), 1620-1633.

Jang J. H., Dempsey B. A. and Burgos W. D. (2008) Reduction of $\mathrm{U}(\mathrm{VI})$ by $\mathrm{Fe}(\mathrm{II})$ in the presence of hydrous ferric oxide and hematite: effects of solid transformation, surface coverage, and humic acid. Water Res. 42(8-9), 2269-2277.

Jerden J. L. and Sinha A. K. (2003) Phosphate based immobilization of uranium in an oxidizing bedrock aquifer. Appl. Geochem. 18(6), 823-843.

Joulian C., Ollivier B., Patel B. K. C. and Roger P. A. (1998) Phenotypic and phylogenetic characterization of dominant culturable methanogens isolated from ricefield soils. FEMS Microbiol. Ecol. 25(2), 135-145.

Junier P., Frutschi M., Wigginton N. S., Schofield E. J., Bargar J. R. and Bernier-Latmani R. (2009) Metal reduction by spores of Desulfotomaculum reducens. Environ. Microbiol. 11(12), 30073017.

Kelly S. D., Kemner K. M., Carley J., Criddle C., Jardine P. M., Marsh T. L., Phillips D., Watson D. and Wu W.-M. (2008) Speciation of uranium in sediments before and after in situ biostimulation. Environ. Sci. Technol. 42(5), 1558-1564.

Kelly S. D., Wu W. M., Yang F., Criddle C. S., Marsh T. L., O'Loughlin E. J., Ravel B., Watson D., Jardine P. M. and Kemner K. M. (2010) Uranium transformations in static microcosms. Environ. Sci. Technol. 44(1), 236-242.

Komlos J., Mishra B., Lanzirotti A., Myneni S. C. B. and Jaffe P. R. (2008a) Real-time speciation of uranium during active bioremediation and U(IV) reoxidation. J. Environ. Eng. 134(2), 78-86.

Komlos J., Peacock A., Kukkadapu R. K. and Jaffe P. R. (2008b) Long-term dynamics of uranium reduction/reoxidation under low sulfate conditions. Geochim. Cosmochim. Acta 72(15), 3603-3615.

Lane D. J. (1991) 16S/23S rRNA sequencing. In Nucleic Acids Techniques in Bacterial Systematics (eds. E. Stackebrandt and
M. Goodfellow). John Wiley \& Sons, Chichester, UK, pp. 115147.

Lee S. Y., Baik M. H. and Choi J. W. (2010) Biogenic formation and growth of uraninite $\left(\mathrm{UO}_{2}\right)$. Environ. Sci. Technol. 44(22), 8409-8414.

Lovley D. R. and Phillips E. J. P. (1992) Reduction of uranium by Desulfovibrio desulfuricans. Appl. Environ. Microbiol. 58, 850856.

Lovley D. R., Phillips E. J. P., Gorby Y. A. and Landa E. R. (1991) Microbial reduction of uranium. Nature 350(6317), 413-416.

Madden A. S., Smith A. C., Balkwill D. L., Fagan L. A. and Phelps T. J. (2007) Microbial uranium immobilization independent of nitrate reduction. Environ. Microbiol. 9(9), 2321-2330.

Marcus M. A. (2010) X-ray photon-in/photon-out methods for chemical imaging. Trends Anal. Chem. 29(6), 508-517.

Moon H. S., Komlos J. and Jaffe P. R. (2007) Uranium reoxidation in previously bioreduced sediment by dissolved oxygen and nitrate. Environ. Sci. Technol. 41(13), 4587-4592.

N'Guessan A. L., Vrionis H. A., Resch C. T., Long P. E. and Lovley D. R. (2008) Sustained removal of uranium from contaminated groundwater following stimulation of dissimilatory metal reduction. Environ. Sci. Technol. 42(8), 2999-3004.

Newville M. (2001) IFEFFIT: interactive XAFS analysis and FEFF fitting. J. Synchrotron Radiat. 8, 322-324.

O'Loughlin E. J., Kelly S. D., Cook R. E., Csencsits R. and Kemner K. M. (2003) Reduction of uranium(VI) by mixed iron(II)/iron(III) hydroxide (green rust): formation of $\mathrm{UO}_{2}$ nanoparticles. Environ. Sci. Technol. 37(4), 721-727.

O'Loughlin E. J., Kelly S. D. and Kemner K. M. (2010) XAFS Investigation of the interactions of U-VI with secondary mineralization products from the bioreduction of Fe-III oxides. Environ. Sci. Technol. 44(5), 1656-1661.

Payne T. E., Davis J. A. and Waite T. D. (1994) Uranium retention by weathered schists-the role of iron minerals. Radiochim. Acta 66(7), 297-303.

Phillips E. J. P., Landa E. R. and Lovley D. R. (1995) Remediation of uranium contaminated soils with bicarbonate and microbial U(VI) reduction. J. Ind. Microbiol. 14, 203-207.

Pickering I. J., Gumaelius L., Harris H. H., Prince R. C., Hirsch G., Banks J. A., Salt D. E. and George G. N. (2006) Localizing the biochemical transformations of arsenate in a hyperaccumulating fern. Environ. Sci. Technol. 40(16), 5010-5014.

Pickering I. J., Prince R. C., Salt D. E. and George G. N. (2000) Quantitative, chemically specific imaging of selenium transformation in plants. Proc. Natl. Acad. Sci. USA 97(20), 1071710722.

Purkhold U., Wagner M., Timmermann G., Pommerening-Roser A. and Koops H. P. (2003) 16S rRNA and amoA-based phylogeny of 12 novel betaproteobacterial ammonia-oxidizing isolates: extension of the dataset and proposal of a new lineage within the nitrosomonads. Int. J. Syst. Evol. Microbiol. 53, 1485-1494.

Ravel B. and Newville M. (2005) Athena, artemis, hephaestus: data analysis for X-ray absorption spectroscopy using IFEFFIT. $J$. Synchrotron Radiat. 12, 537-541.

Ray A. E., Bargar J. R., Sivaswamy V., Dohnalkova A., Fujita Y., Peyton B. M. and Magnuson T. S. (2011) Evidence for multiple modes of uranium immobilization by an anaerobic bacterium. Geochim. Cosmochim. Acta 75(10), 2684-2695.

Rehr J. J. and Albers R. C. (2000) Theoretical approaches to X-ray absorption fine structure. Rev. Mod. Phys. 72(3), 621-654.

Sass H., Overmann J., Rutters H., Babenzien H. D. and Cypionka H. (2004) Desulfosporomusa polytropa gen. nov., sp nov., a novel sulfate-reducing bacterium from sediments of an oligotrophic lake. Arch. Microbiol. 182(2-3), 204-211. 
Schofield E. J., Veeramani H., Sharp J. O., Suvorova E., BernierLatmani R., Mehta A., Stahlman J., Webb S. M., Clark D. L. and Conradson S. D., et al. (2008) Structure of biogenic $\mathrm{UO}_{2}$ produced by Shewanella oneidensis MR-1. Environ. Sci. Technol. 42(21), 7898-7905.

Sharp J. O., Schofield E. J., Veeramani H., Suvorova E. I., Kennedy D. W., Marshall M. J., Mehta A., Bargar J. R. and Bernier-Latmani R. (2009) Structural similarities between biogenic uraninites produced by phylogenetically and metabolically diverse bacteria. Environ. Sci. Technol. 43(21), 8295-8301.

Singh A., Ulrich K. U. and Giammar D. E. (2010) Impact of phosphate on U(VI) immobilization in the presence of goethite. Geochim. Cosmochim. Acta 74, 6324-6343.

Sivaswamy V., Boyanov M. I., Peyton B. M., Viamajala S., Gerlach R., Apel W. A., Sani R. K., Dohnalkova A., Kemner K. M. and Borch T. (2011) Multiple mechanisms of uranium immobilization by Cellulomonas sp. strain ES6. Biotechnol. Bioeng. 108(2), 264-276.

Stookey L. L. (1970) Ferrozine, a new spectrophotometric reagent for iron. Anal. Chem. 42, 779-781.

Suzuki Y., Kelly S. D., Kemner K. M. and Banfield J. F. (2002) Nanometre-size products of uranium bioreduction. Nature 419(6903), 134-135.

Sylwester E. R., Hudson E. A. and Allen P. G. (2000) The structure of uranium (VI) sorption complexes on silica, alumina, and montmorillonite. Geochim. Cosmochim. Acta 64(14), 24312438 .

Templeton A. S., Knowles E. J., Eldridge D. L., Arey B. W., Dohnalkova A. C., Webb S. M., Bailey B. E., Tebo B. M. and Staudigel H. (2009) A seafloor microbial biome hosted within incipient ferromanganese crusts. Nat. Geosci. 2(12), 872-876.

Tokunaga T. K., Wan J. M., Kim Y. M., Sutton S. R., Newville M., Lanzirotti A. and Rao W. (2008) Real-time X-ray absorption spectroscopy of uranium, iron, and manganese in contaminated sediments during bioreduction. Environ. Sci. Technol. 42(8), 2839-2844.

Ulrich K. U., Ilton E. S., Veeramani H., Sharp J. O., BernierLatmani R., Schofield E. J., Bargar J. R. and Giammar D. E.
(2009) Comparative dissolution kinetics of biogenic and chemogenic uraninite under oxidizing conditions in the presence of carbonate. Geochim. Cosmochim. Acta 73(20), 6065-6083.

Ulrich K. U., Singh A., Schofield E. J., Bargar J. R., Veeramani H., Sharp J. O., Bernier-Latmani R. and Giammar D. E. (2008) Dissolution of biogenic and synthetic $\mathrm{UO}_{2}$ under varied reducing conditions. Environ. Sci. Technol. 42(15), 5600-5606.

Veeramani H., Alessi D., Suvorova E., Lezama-Pacheco J., Stubbs J., Sharp J., Dippon U., Kappler A., Bargar J. and BernierLatmani R. (2011) Products of abiotic U(VI) reduction by biogenic magnetite and vivianite. Geochim. Cosmochim. Acta 75(9), 2512-2528.

Wazne M., Korfiatis G. P. and Meng X. G. (2003) Carbonate effects on hexavalent uranium adsorption by iron oxyhydroxide. Environ. Sci. Technol. 37(16), 3619-3624.

Webb S. M. (2005) SIXPACK: a graphical user interface for XAS analysis using IFEFFIT. Phys. Scripta T115, 1011-1014.

Wersin P., Hochella M. F., Persson P., Redden G., Leckie J. O. and Harris D. W. (1994) Interaction between aqueous uranium(Vi) and sulfide minerals - spectroscopic evidence for sorption and reduction. Geochim. Cosmochim. Acta 58(13), 2829-2843.

Wu W. M., Carley J., Luo J., Ginder-Vogel M. A., Cardenas E., Leigh M. B., Hwang C. C., Kelly S. D., Ruan C. M. and Wu L. Y., et al. (2007) In-situ bioreduction of uranium (VI) to submicromolar levels and reoxidation by dissolved oxygen. Environ. Sci. Technol. 41(16), 5716-5723.

Yabusaki S. B., Fang Y., Long P. E., Resch C. T., Peacock A. D., Komlos J., Jaffe P. R., Morrison S. J., Dayvault R. D. and White D. C., et al. (2007) Uranium removal from groundwater via in situ biostimulation: field-scale modeling of transport and biological processes. J. Contam. Hydrol. 93(1-4), 216-235.

Zhou P. and Gu B. H. (2005) Extraction of oxidized and reduced forms of uranium from contaminated soils: effects of carbonate concentration and pH. Environ. Sci. Technol. 39(12), 44354440 .

Associate editor: Christopher S. Kim 